\title{
STEM-EDUCATION DURING THE STUDY OF NATURAL CYCLE DISCIPLINES AS A LEADING COMPONENT OF MODERN INNOVATIVE PERSONALITY
}

\section{Yana Prystupa ${ }^{1}$}

DOI: https://doi.org/10.30525/978-9934-26-076-6-14

Today, the concept of STEM is one of the main trends in educational policy in many developed countries, which provides an opportunity to strengthen the science component in the curriculum. The quality of education is determined by the competence and level of professional activity of the teacher, so it is important while studying at the Pedagogical University to form the professional competencies of future teachers in the areas and issues of STEM-education. Now we need a new person with a certain system of knowledge, mindset, developed thinking, the ability to make optimal decisions depending on the situation.

STEM education is widely used in countries such as the United States, Great Britain, Israel, Australia, Singapore, China, Korea. Conceptual aspects of the problem of STEM-education were considered in the works of foreign (George Lucas, Georgette Yakman, Jonathan W. Gerlach) and domestic scientists (I. Vasilashko, S. Galata, O. Korshunova, N. Morse, O. Patrikeeva and others).

In Ukraine, in 2016, the spread and development of STEM education was initiated. In particular, the "Action Plan for the implementation of STEM education in Ukraine for 2016-2018» was developed. A number of orders were presented by the Ministry of Education and Science of Ukraine (hereinafter - MES) (MES order of April 13, 2018 № 366 «On the implementation of an innovative educational project at the national level on» I am a researcher «for 2018-2021», MES order from May 17, 2017 № 708 «On conducting research and experimental work at the national level on the topic:» Scientific and methodological principles of creation and operation of

\footnotetext{
${ }^{1}$ Kryvyi Rih State Pedagogical University, Ukraine
} 
the All-Ukrainian scientific and methodological virtual STEM-center (VNMV STEM-center) «for 2017-2021») and the Institute for Modernization of Educational Content (hereinafter - IMEC) (IMEC order of February 5, 2020 № 8 «On the festival» STEM-Spring - 2020 «, IMEC order of November 13, 2019 № 113» On the organization and conduct of research « Efficiency of educational processes in the conditions of modernization of the educational sector «, IMEC order of August 14, 2019 № 68 (On the organization and conduct of» STEM-school - 2020 «) (Orders of the Ministry of Education and Science of Ukraine) [3].

The concept of «innovation» is not just the creation and dissemination of innovations, but also transformations that are significant in nature and are accompanied by changes in the way of activity, style of thinking. It is STEM technology that aims to make it clear to students that learning can be fun, exciting, and not just memorize a paragraph from a textbook, but do many extremely useful things that a few years ago we could not even think about. For example, display the structure of a leaf on a digital microscope, and then send it to smartphones so that students can look. It is the digitalization of the educational process that will contribute to the formation of positive motivation for learning and the transfer of cognitive information, the means of which are computers and modern gadgets. Biological educational web resources have already been developed today (distance biology study courses: edera.com; courser.org; khanacademy.org; alison.com; interactive training programs: star.mit.edu; biology study courses: EdEra www.courses.ed era.com/courses/course-v1: EdEra-Osvitoria + BIO + $1 /$ about; biological databases: protein database www.resb.org/; gene database www.nebi.nlm.gov/gene; database genomes www.ensemblgenomes.org; chemical and biochemical infographics www.compoundchem.com; Wikipedia. Free encyclopedia http://wikipedia.org; Nobel Prize winners http://nobelprize.org; Ukrainian biological site: http: // biology.org; http://my.science.ua; microbiology online http://microbiologyonline.org; Science Museum / SSPL https://blog.sciencemuseum.org.uk; international natural science game «Helianthus» helianthus.com. ua); statistical parameters of the population. Spatial distribution. General Ecology (Online Lecture Course): website. URL: https: //bitly.su/Bq8L), virtual tours and laboratories, simulation simulators that make learning accessible and creative.

Today, the priority in the teaching of biology is STEM-education, in which the curriculum significantly enhances the scientific component in combination with innovative technologies.

The acronym STEM is used to denote a popular field of education that encompasses the natural sciences technology engineering and mathematics. 
The term «STEM-education» is a marker used in the values of different content:

- in the narrowest sense, it refers to a set of training programs and courses aimed at training scientific and scientific and technical personnel of the highest qualification (level of candidates and doctors of sciences), capable of conducting scientific (fundamental and practical) research in STEM areas;

- in a broader sense, it refers to a set of training programs and courses aimed at training in the fields of STEM in addition to scientific and scientifictechnical and engineering-technical personnel (bachelors and masters), able to create (develop) and operate (improve) the latest, so so-called high technologies and high-tech equipment;

- in the broadest sense, it refers to a set of training programs and courses aimed at training in the fields of STEM qualified scientific and technical personnel of all levels (including workers), able to work in high-tech (knowledge-intensive) industries and service (including repair and operation of high-tech technique [1].

Ukrainian STEM education specialists note that «STEM education is a series or sequence of courses or training programs that prepares students for successful employment, after-school education, or both, requires different and more technically complex skills, including the use of mathematical knowledge and scientific concepts. In world practice, there is no single understanding of this concept» [2].

Also STEM-education is a category that determines the relevant pedagogical process (technology) of formation and development of mental and creative qualities of students, the level of which determines the competitiveness in the modern labor market: the ability and willingness to solve complex problems (problems), critical thinking, creativity, cognitive flexibility, cooperation, management, innovation.

The introduction of STEM education promotes the development of abilities for research, analytical work, experimentation and critical thinking. Early involvement of students in STEM can support not only the development of creative thinking and the formation of the researcher's competence, but also contribute to better socialization of the individual, because it develops such skills as cooperation, communication, creativity.

Introduction of methodical decisions of STEM-education in educational process will allow to form in pupils the most important characteristics defining the competent expert: ability to see a problem, ability to see in a problem as many possible parties and communications, ability to formulate research questions and ways of its decision, flexibility. As the ability to understand a new point of view and resilience in defending their position, originality, departure from the template, the ability to concretize or synthesize 
a sense of harmony in the organization of the idea. The implementation of STEM-education approaches assumes that pupils / students simultaneously learn about technology (for example, schemes), about the field of knowledge (for example, mathematics and acquire skills (for example, cooperation, coding).

Today STEM-approaches are implemented in many Ukrainian schools, including in our region. For example, educational games in the field of STEM complement traditional training in science and technology. Their purpose is to help schoolchildren and students to bridge the gap between educational tasks and the real activities of a scientist and engineer. STEM games are models of geology and atmosphere, ecology and astrophysics. Interacting with them, the student chooses the research strategy, ie acts not as a student, but as an independent researcher, designer. The ability to use the educational game in the course of physics or biology is an important addition to the competencies of a science teacher.

Thus, the use of STEM-education technologies in the study of natural cycle disciplines will maximize their effectiveness, create conditions for the formation of holistic natural knowledge, basic life competencies and scientific picture of the world of applicants; development of creative thinking, independence and creative activity; improvement of research skills and the formation of innovative thinking, new cognitive values, which are the basis of intellectual growth of the individual, able to create innovations, which is the main goal of STEM-education.

\section{References:}

1. About understanding of the Concept of development of natural and mathematical education (STEM-education). URL: https://zakon.rada.gov.ua/laws/ show/960-2020-\% D1\% 80 \# Text

2. Ivanyuk T. (2017) STEM as an educational resource of the XXI century. STEMeducation and ways of its implementation in the educational process. Ternopil, pp. 14-18.

3. Official site of the Institute for Modernization of the content of education, (2016-2017). URL: http://www.imzo.gov.ua/stem-osvita/ 